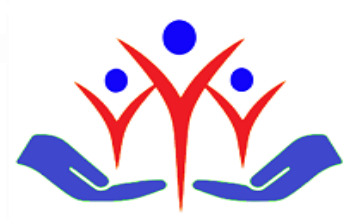

ISSN 2458-8865 failure: a qualitative research

\title{
Sınıf tekrarı yapan tıp öğrencilerinin akademik başarısızlığa bakışları: niteliksel araştırma
}

\section{Halime Seda Kucukerdem", Esra Meltem Koc ${ }^{\mathbf{b}}$, (D) Huseyin Can}

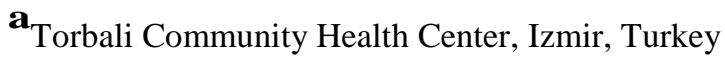

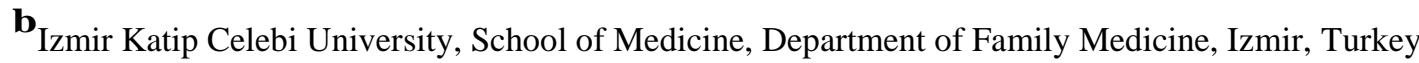

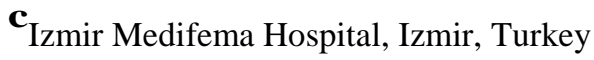

\begin{abstract}
Introduction: There are many quantitative studies on academic failure in the medical faculty. This study aimed to investigate the opinions of students who were having an academic failure in the medical school and to reveal the underlying causes.

Methods: The study was designed as a qualitative research. The population of the study comprised of students failed while they were studying at the İzmir Katip Çelebi University Faculty of Medicine during the 2014- 2015 academic year. Failure was defined as the repetition of a study year. Thus, phase 4 and 5 students were not included. The study sample was composed of medical students who failed at phase 1, 2, or 3, chosen by quota sampling. Data was collected using semi-structured questions asked by face-to-face interviews. The interviews were done between April-May 2016. A personal information form was used to collect data related to the students' socio-demographic, individual, and academic characteristics. Thematic analysis was used for data analysis.

Results: After the interpretation was made by four researchers, the following themes were created: Opinions and beliefs of the students about the effects of faculty on academic success; attitudes, beliefs, and opinions on study behaviors; feelings and believes on becoming a medical doctor; and views about the impact of the social environment. It was determined that the most frequently mentioned factor by the students as the leading cause of their repetition of the class was an insufficient academic effort. Other remarkable topics were; students not benefiting from counseling services and not attending the lectures of instructors of whom they didn't like the way of presentation and lecturing.

Conclusions: Introducing students about advisory services given by lecturers and providing advice from their experienced advisors especially to the students who repeat classes, can contribute to academic success. Training of lecturers on effective lecturing can contribute to academic achievement by increasing the attendance of students. Giving due importance to introduce the occupation from the early days of education can improve the motivation to learning.
\end{abstract}

Keywords: Academic failure, faculty of medicine, qualitative research

\section{ÖZ}

Giriş: Tıp fakültesinde akademik başarısızlık ile ilgili birçok niceliksel çalışma mevcuttur. Bu çalışmanın amacı, tıp fakültesinde akademik başarısızlık alan ögrencilerin, bu konuya bakış açılarının derinlemesine incelenmesi ve altta yatan nedenlerin ortaya konulmasıdır.

Yöntem: Çalıșma niteliksel araștırma deseninde tasarlandı. Araștırmanın evrenini 2014-2015 öğretim y1lında İzmir Kâtip Çelebi Üniversitesi Tıp Fakültesi’nde öğrenim gören ve başarısızlık alan öğrenciler oluşturdu. Başarısızlık, sınıf tekrarı olarak ele alındığından dönem 4 ve 5 stajlarında başarısız olan öğrenciler çalışmaya dahil edilmedi. Araştırmanın örneklemini sınıf tekrarı yapan dönem 1, 2 ve 3 öğrencilerinden kota örnekleme yöntemiyle seçilen öğrenciler olușturdu. Veri toplama aracı olarak yüz yüze görüşme tekniği kullanılarak yarı yapılandırılmış sorular yöneltildi ve görüşmelerin ses kaydı tutuldu. Röportajlar, Nisan-Mayıs 2016 tarihleri arasında yapıldı. Öğrencilerin sosyo-demografik, kişisel ve akademik niteliklerine ilişkin veri toplamak amacıyla oluşturulan Kişisel Bilgi Formu kullanıldı. Verilerin analizinde tematik analiz kullanıldı.

Bulgular: Dört kişi tarafindan yapılan çözümlemeler sonucunda temalar oluşturuldu: Öğrencilerin fakültenin akademik başarı üzerine etkileri hakkında görüş ve inançları, Calıșma davranıșları ile ilgili tutum, inanç ve görüșler, Hekimlikle ilgili duygu ve inançlar, Sosyal çevrenin etkileri hakkındaki görüșler. Analizler sonucunda öğrencilerin yeterli ders çalışmamalarının sınıf tekrarı yapmalarında en sık dile getirilen etmen olduğu belirlendi. Dikkat çeken diğer konular ise öğrencilerin danıșmanlık hizmetlerinden yararlanmamaları ve sunum ve anlatıs șeklini beğenmedikleri öğretim üyelerinin derslerine devam etmemeleriydi.

Sonuç: Öğretim üyeleri tarafından verilen danışmanlık hizmetleri ile ilgili öğrencilere detaylı bilgilendirmenin yapılması ve özellikle sınıf tekrarı yapan öğrencilere bu konuda yetkin eğiticilerce danışmanlık hizmeti sağlanması ile akademik başarıda artış sağlanabilir. Eğiticilere etkili ders anlatımıyla ilgili eğitimler verilmesi ile de öğrencilerin derse devamlılı̆ı̆ı sağlayarak akademik başarıları artırılabilir. Fakültenin ilk günlerinden itibaren mesleki tanıtıma gerekli önemin verilmesi ile öğrencilerin öğrenme motivasyonları artırılabilir.

Anahtar kelimeler: Akademik başarısızlık, tıp fakültesi, niteliksel çalışma

\begin{tabular}{|c|l|c|c|c|}
\hline Received & \multicolumn{1}{|c|}{ Accepted } & Published Online & Corresponding Author & E-mail \\
\hline July 24, 2018 & November 27, 2018 & March 19, 2019 & Halime Seda Kucukerdem, MD & sedaboz@gmail.com \\
\hline Correspondence & $\begin{array}{l}\text { Halime Seda Kucukerdem, Torbali Community Health Center, Ertugrul Mah, 3077 st, Torbali, Izmir, } \\
\text { Turkey }\end{array}$ \\
\hline
\end{tabular}




\section{Introduction}

Being a university student is a longing desired and awaited success to many young people along with being a transition from adolescence to adulthood [1]. Youth can be a period of confrontation with difficulties due to factors such as bodily changes resulting from rapid growth, an increase in sexual drives, yet immature identity, and ambiguous social place [2]. From the moment students step into the university, they enter an area which may seem foreign, consists of different features, and is brand new to them. As to Koç and Polat, university life has been defined as a new and challenging period for the youngster who has to carry out many responsibilities solitary while leaving the family [3]. Medical education continues in a process where students have many responsibilities.

Based on the fact that medical faculties are the only source for training physicians, academic achievement is of particular significance in evaluating this period [4]. Academic success is defined as "the level of achievement of behaviors expected from the students at school" [1,4]. Academic failure, on the other hand, is defined as an achievement less than expected, based on the individual's cognitive ability. In the literature, various factors affecting academic achievement are mentioned, and academic failure is generally associated with factors such as motivation, organization, goal setting, self-control, self-efficacy, family environment, psychological conditions, and friends of the individual [1,5-7]. Factors that cause academic failure in the university can be discussed under three headings. These are; student-based, appropriateness of the classrooms and the teaching tools, and measurement techniques used by the instructor and the instructor [8].

After the university reforms in the Republican Period, the Faculty of Medicine at the University of Istanbul was opened as the first and only medical school in Turkey on November 1, 1933 [9]. With the effects of the German education system, using a classical education approach and an instructor-centered training program consisting of amphitheater classes, medical education has been started. Later on, with the initiation of Hacettepe University Faculty of Medicine in 1963, an educational-oriented, organ-based integrated education program approach consisting of amphitheater classes was implemented. This successful integrated system has also been adopted by many medical faculties afterwards [10,11]. In 1996, The Faculty of Medicine at Dokuz Eylül University undertook a reform in the educational program and reconstructed the entire curriculum with a learner-centered, problem-based learning approach $[9,12]$.

Medical school education has different study periods in different countries. For example, the period of training, which is usually four years in the United States, lasts from five to seven years in China. The medical school is a six-year-long undergraduate education process in Turkey. The first three years are usually given in the form of basic sciences education, followed by two years of clinical training and one year of internship [13]. Just like the education methods, also the assessment and evaluation systems have similarities and differences between medical faculties. There are students entering committee exams, exams for separate courses, those without any final exams, and thus, perhaps from two students with the same level of knowledge, one can pass the academic success limits, while the other one fails.

In İzmir Katip Çelebi University Faculty of Medicine, the language of instruction is Turkish, and in the 2014-2015 academic years, education and examinations were carried out with the integrated committee system for the first three study years. At the time of this study, the faculty of medicine had yet no graduated students [14].

This study aimed to put forward the factors students with academic failure in the medical school perceive as the reasons of their failure in depth and from the students' point of view, to determine the status quo, and discuss ideas on what could be done to increase the academic success.

\section{Methods}

\section{Study design}

This study was carried out as a qualitative phenomenology study. Phenomenology constitutes an appropriate research base for studies aiming at investigating the phenomena in which we are not completely unfamiliar with but cannot embrace the exact meaning [15]. The main data collection methods in this study were one-to-one and in-depth interviews. The aim of the data analysis in phenomenological research is revealing experiences and contents. In this context, efforts were made to conceptualize data and identify themes that could identify the phenomenon. The results were presented with descriptive narration and frequent direct quotations. The findings were explained and interpreted within the framework of emerging themes and patterns. The ethical permission of the study was obtained from the ethics committee of Katip Çelebi University Atatürk Training and Research Hospital (25.02.2016; Decision no: 16).

\section{Participants}

The population of the study consisted of the students who had education in the Faculty of Medicine at the İzmir Kâtip Çelebi University in the 2014-2015 academic years. The full list of students who repeated the 2014-2015 academic years and their contact information was obtained through the student affairs by obtaining permissions from the dean's office. In qualitative research, the quota sample is determined by the basic qualifications established for the purpose of the research. In this research, our purpose-oriented quota were semester 1-2-3 students who repeated the class due to academic failure. We aimed to include all students who repeated the terms 1,2, or 3 . For the interviews, the students were contacted via phone, and those who agreed were invited with an appointment. Only one student repeated the third grade with whom an interview could not be set. For this reason, interviews were done with the 1st and 2nd-grade students. Interviews were completed when the participants' sound recordings reached satiety and repetitions started.

\section{Data collection process}

Semi-structured, face-to-face interviews were planned for data collection. All interviews were held between April and May 2016. Each interview lasted approximately 30-80 minutes. Care was taken to provide an interview environment where the interviewees could feel comfortable and 
peaceful and could easily explain their views. The students were not given time constraints and were given as much time as they needed to answer questions. A Personal Information Form was used to collect questions about the socio-demographic, personal, and academic qualifications of the students. The interview questions were composed after a literature search by the researchers, aiming to include the reasons of academic failure of the students including individual characteristics, family, friends, educators, study habits, learning environment, and academic counseling services. In the preparation of the interview questions, care was given that the questions were easy to understand, not multidimensional, and not directing the respondent to a specific answer. A pilot interview was conducted with an experienced researcher and amendments were done to the interview questions before beginning with the actual interviews. The questions were asked by one-on-one interview, and the voices were recorded. Notes were taken about conspicuous expressions and gestures during the interview. When the respondents started repeating similar statements, the interviews were wrapped up, accepting that a satiety point was reached.

Within the framework and aim of the study, answers to the following questions were sought after the literature review:

1. How do you think the socio-demographic characteristics have an impact on academic achievement? Can you evaluate the situation?

2. How do the students' individual qualifications (studying routines etc.), affect their academic success?

3. How do familial features play a role in the academic achievement of the students?

4. Are friendships/relationships and academic achievements influenced by each other?

5. Are trainer characteristics and consulting services influencing academic achievement?

6. How does the learning environment have an impact on students' academic success?

7. What are the characteristics that affected your academic failure?

\section{Data analysis}

Audio recordings of the interviews were listened and decoded. When converting into text, emotions that didn't put into words, but could be observed by the researcher (like students' voice tone, sadness, anxiety, joy, etc.) and researchers' notes for the body language movements and gestures were enlisted. To increase the reliability of the study, the written texts obtained from the analysis of all interviews were examined separately by the three researchers (apart from the researcher who did the interviews) and an agreement was reached in the decoded texts. The non-verbal, as well as verbal expressions, were evaluated during the analysis. After four researchers analyzed the texts that were most repetitive and expressing as many different ideas as possible, a consensus on the open codes was met. Sub-themes were reached by the selective coding of the main themes. Thematic analysis was used to analyze the data. The real names of the participants were not included in the study; only code names were used.

Words related to each other in the selective codes were grouped under "Sub Themes." The sub-themes were evaluated among themselves and were grouped under "Themes" making up more comprehensive common headings (Figure 1). All sentences were taken into consideration in the assessment, even if they were left out of the existing themes or expressed by a single participant. The results of the study were interpreted within the framework of general themes.

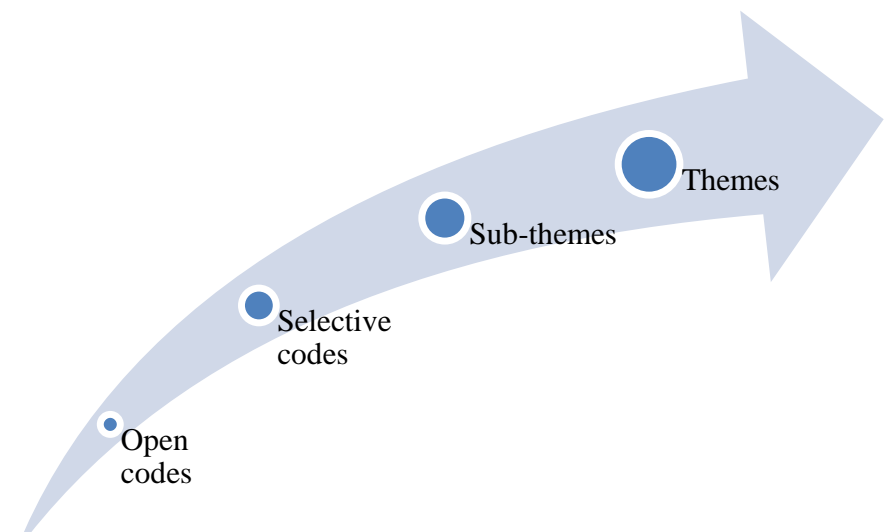

Figure 1. Construction of the themes

\section{Results}

A total of 12 students were included in the study. Four of the students were female, and eight were male. Six of the students participated in the study were first, and the other six were second-year students. The students were between the ages of $19-24$, and the mean age was $21 \pm 1.27$ years. 
Four students were staying in dormitories, and four students said they were living with their family. There were 9 interviewees who moved to another town to study university. Some descriptive features of the students are presented in Table 1.

Table 1. Descriptive characteristics of the participants

\begin{tabular}{lclcllll}
\hline \# & Age & Sex & Study year & Accommodation & Income-expenses & Mother's education & Father's education \\
\hline G 1 & 21 & Male & 1 & Student dorm & Balanced & University & Middle school \\
G 2 & 21 & Male & 1 & Student dorm & Balanced & Primary school & High school \\
G 3 & 20 & Female & 1 & Student dorm & Balanced & Primary school & Primary school \\
G 4 & 19 & Male & 1 & With family & Positive & University & University \\
G 5 & 21 & Male & 2 & With family & Positive & University & University \\
G 6 & 20 & Male & 2 & Other (grandmother) & Positive & University & University \\
G 7 & 21 & Female & 2 & With family & Positive & University & University \\
G 8 & 24 & Male & 2 & Alone & Positive & High school & University \\
G 9 & 21 & Female & 2 & With peers & Positive & High school & Primary school \\
G 10 & 22 & Male & 1 & Student dorm & Balanced & Primary school & High school \\
G 11 & 20 & Male & 2 & With family & Balanced & University & University \\
G 12 & 22 & Female & 1 & With peers & Balanced & University & University \\
\hline
\end{tabular}

While creating themes, first, sub-themes that will enable us to address the issue in all aspects were identified, and themes were gathered under subthemes, which were related to each other in meaningful topics. The themes determined in the analysis are listed in Table 2.

Table 2. Themes determined in the investigation.

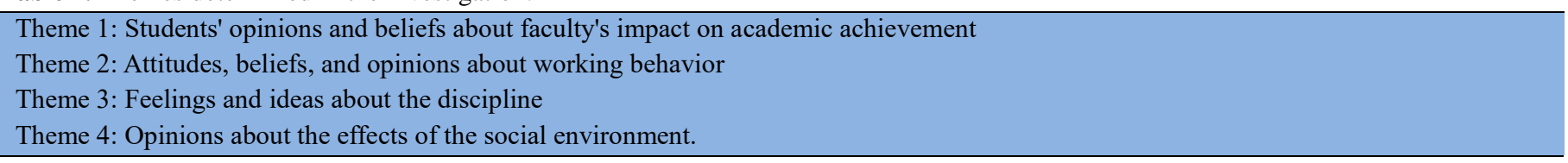

Among the students interviewed, G10 came from a different country to get a better education at the university. All interviewers except for G12 said that this was their first failure; however, G12 had to repeat the class twice. Three interviewers stated that after graduating from high school, they continued to prepare for higher education selection exams to study medicine.

When initiating the interviews, all students were questioned about socio-demographic data and asked whether they had any factors associated with their academic achievement related to the questions in the personal information form. The vast majority of the students stated that there was no such a factor.

"I don't think there's anything about this." (G1)

"No, nothing." (G10)

However, when they were re-directed to their responses individually via statements such as "What do you think for example about...?" they stated that there could be some relationship.

"I mean, maybe there is a little influence of the dormitory" (G1)

"Yes, there is... a small middle-Anatolian city, let me say, "classical." I realized that Izmir is much different than middle or eastern Anatolia" (G2)

"Turkey was strenuous for me for the first one or two months" (G10)

In the interviews, most of the students thought that insufficient studying was the biggest factor in their failure, but they could not explain the reason behind.

“...I did not study, and I am aware of that.” (G7)

"I seemed to be studying, but actually I was not." (G9)

"I did not study enough... Why this... (thinks) overtly, I am not sure.” (G11)

Some of the students interviewed did not have a clear plan for the department they wanted to work at after graduation.

"I didn't think yet about the branch; I think as I get more into medicine, my mind will get clear. Then I may have a few options." (G4)

"I was thinking about being a psychiatrist in the first grade; then I shifted to surgery. Probably more shifts will be there. So I don't have a clear idea right now." (G7) 
"Right now, I really want only to finish. I'm a person who plans and thinks a lot for the future, but here I can't think of anything."(G12)

The themes and sub-themes examined under themes were discussed in the following order:

1. Perceptions and beliefs of students about the effects of the faculty on academic achievement:

The sub-themes listed below were used in the formation of this theme.

- $\quad$ Issues related to trainers

- $\quad$ Thought on the committee and exams

- $\quad$ Features related to the learning environment

- $\quad$ Practice courses

- Weight of the theory education

- Counseling

The interviewees mostly expressed that the trainers had sufficient knowledge, but the teaching techniques significantly affected the usefulness of the course and their decision to attend. It was noteworthy that there were periods when they did not study because of the two-month duration of the committees, and they lost the thread. Some participants expressed opinions that they experienced difficulties with the minimum thresholds applied in the exams. However, it was observed that there were positive thoughts about the integrated course system. The interviewees did not say that they met the counselor except for one interviewer who met his adviser for a shortage about the course registration. It was observed that the majority of the interviewees did not know enough about the academic counseling services, and some of them did not believe that they would benefit from it. Some participants expressed their opinion that it would be useful if met with the consultant. The views on the theoretical part of the courses were generally in the direction that they could be managed if studied, but the intensity was too high. They stated that the hardest situations were courses requiring too much memorization.

"I think, most of our trainers are very well-intentioned, but in fact, it is really impossible to listen to some of our lecturers, that is, we have some lecturers talking with such a low voice for two hours, and then the attention of the people begins to fall... We can't listen to these teachers and try to use our absenteeism quota..." (G1)

“...but some instructors are good indeed; I'm trying not to miss them. I have especially some instructors in my mind, which I try not to miss.” (G2)

“... I do not feel very sufficient in many ways. There are such very elementary questions... Sometimes I cannot get answers from teachers or something; this makes me question whether I'm in a good place to study." (G3)

"First of all the teacher must be good in lecturing; everything depends on the teacher. It doesn't matter whether they give all kinds of details in the slides or provide pictures!" (G5)

“...for example, removing the minimum threshold to be done in the exams would be great" (G1)

“...I can study easier if the duration of the courses is short; otherwise, in some long courses, I give up from the beginning." (G2)

"To me, the difficulty level of our exams is ideal; they are neither difficult nor easy." (G4)

"I think, the integrated system is better. In the schools who have separate courses, one teacher instructs about urogenital while the other on GIS."(G5)

“...the exam system has its pros and cons. To me, the difficult side is that you are assessed only five times throughout the year; means once every two months." (G6)

"I wish only there would be no threshold passing in the exams. That means I do not have any other problem... for example, no matter how steadily I study, I get stuck during the second/third readings. This is something related to the system." (G9)

2. Attitudes, beliefs, and opinions about working behaviors:

The following sub-themes have been used to create this theme:

- $\quad$ Individual Features

- Not studying, issues related to the study method

- Study habits

Fam Pract Palliat Care. 2019 Apr;4(1): 
- $\quad$ Opinions about mood

- Approach to course attendance

- $\quad$ Library use

- $\quad$ Feelings related to academic failure

- $\quad$ Reason for not studying/fail

- $\quad$ Compliance

When the opinions of the students about working, lack of studying, and mistakes were examined, all the interviewees expressed their perception as "I didn't work." When were they asked to think about the reasons for this, it revealed that some wanted to relax after the exam marathon from high school, others had the perception that university education should be easier, some said that they had an easygoing personality, and others stated that they couldn't guess a reason. When the interviewees' statements about attending classes were examined, there was a common belief that participation in the class made it easier to study and learn before the exam. Despite this, the majority had low attendance. It was observed that the instructors' style of lecturing was the most decisive factor for attendance. When the interviewees were asked about what they thought to be the reasons regarding not studying and repeating their class, it was observed that there were individual differences in the responses. Many different factors were expressed, including the relationship with the opposite sex, depressive mood, family conflicts, and lack of motivation for studying.

“..I was thinking, so my mind was going elsewhere, so this year I dedicated myself completely to staying; spiritually and physically I give myself to the lectures."(G3)

"I'm too much relaxed, and, there is also the thing, they said university shall be a bit comfortable, after the tight schedules at high school. I had that slackness, and so, we were hanging out." (G5)

“..there is too much verbal load at the school. All my life, I am used to studying without memorizing. Probably I couldn't adapt.”(G6)

“..I didn’t study, and I am aware of that. You know, I think, that's why I failed.” (G7)

"I study so hard to one topic, then because of the threshold system, I do excellent in let's say physiology, but while studying physiology, I neglect anatomy and am hit by the threshold."(G12)

"Of course it has benefits when memorizing. If you never listened, it becomes much difficult to learn." (G4)

"It's easier if you attend at least 1-2 lectures at the beginning and join the first two weeks; then you can easily catch up." (G5)

“...even if you just listen once, it makes it easier to study at home, even this bit has benefits.”(G6)

“Hmmm.. It happened after I separated from my girlfriend. Unfortunately, with great probability, she was the reason.”(G1)

“..for example, I would have not failed if I had not been in that dorm the last year..." (G2)

“...lecture notes accumulated as big as mountains. How can one finish them? Once you have this in mind, then you start to have distrust to yourself. Then, enthusiasm and motivation fade." (G5)

“...let's say, I would have passed if I studied last year. The reason is that I did not study.” (G7)

"Why I not studied, this (thinks), openly, I do not know. Probably it was too tough. The requested study load was too much.” (G11)

3. Feelings and beliefs related to the discipline:

The following sub-themes have been used to create this theme:

- $\quad$ Reasons to choose medicine

- $\quad$ Family's view of medical school

- Motivation for school attendance

- $\quad$ Future dreams, thoughts of becoming a doctor

Among the reasons why the interviewees preferred medical school were those who had dreamed of becoming a doctor since their childhood, as well as those who were directed to study medicine by the family and high school teachers. They preferred to study medicine, especially due to the 
potentially high income, job guarantee, and prestige. The majority preferred to study medicine without any motivation related to the discipline itself, but because of the score they had taken from the placement examination during the matching period. Those who stated that their motivation to become a physician increased after they joined the school, stated that their attendance to the classes and the success in the courses during the following year increased. Some participants expressed their concerns about the TUS exam (a specialty placement exam in Turkey) and compulsory service. They stated that this was an obstacle for dreaming of their future career. The participant number 12 stated that he got an interest in oncology after his mother was diagnosed with cancer.

“....after you finish, you have the work. I mean, it is guaranteed. You have a good salary too.” (G2)

"I selected medical school because... There is no worry about work, primarily because of this... I think the salary has a significant role too.” (G4)

"I was encouraged by the family, teacher, and environment. My parents wanted it more than myself. Always their covered message was 'select medicine, select medicine'.” (G5)

"In the first year, I wanted to become a psychiatrist, then it shifted towards surgical. Probably there will be more shifts. I mean... currently, I have no clear idea." (G7)

"I have no plans what I will do after finishing medicine. Because, two years I will lose because of the law, then specialization, then another two years, and then military service... When I get my certificate, I will be probably 38 ” (G8)

"I started to consider oncology after the condition of my mother." (G12)

4. Opinions about the effects of the social environment:

The following sub-themes have been used to create this theme:

- $\quad$ Sharing with the family

- $\quad$ Friendships - achievements

- Extracurricular time-social activities

- Income and living conditions

- $\quad$ Conditions specific to housing

- Nutrition

- Relationships with the opposite sex

If the participants had good relationships with their families, they perceived it as in the direction of support, if the family relations were not sufficient, they felt no effect on their success, and they were negatively affected if their relationships were conflicting. In particular, the interviewees who had family conflicts did not see support from their families about studying in the medical school. Some students said that they needed help from their families about their studies and school attendance. The majority of the interviewees stated that when they repeated the class, they were supported by the family and were not criticized. However, they did not share their feelings and thoughts about what this support meant to them. It was observed that the support and the friendship groups they created for studying had positive effects on the academic achievements of the students. There were some who expressed their opinion that staying with a friend of his class would contribute to success. On the other side, some of the interviewees who made a city change for the university felt loneliness, and this made the adaptation process more difficult. To study one more year after high school caused an age difference between the student and his classmates, and this made it difficult for some students establishing healthy relationships. Many interviewees stated that the housing conditions had effects on more than one area such as study, sleep, and nutrition. None of the participants established a relationship between nutrition opportunities and academic achievement. There was one student who expressed that the emotional difficulty he experienced after separation from his girlfriend led to failure.

“...they did not preach and also did not do other things, they accepted it as very, I mean... mature.” (G1 )

"They have a lot of support, I mean as medical school, they support in the sense of helping others and receiving prayers, the possibly most honorable work!"'(G2)

"From the spiritual standpoint, I did not receive any support from my family up to this age." (G3)

“They are fanatic for regular attendance. They say 'You learn by listening'." (G5)

“They supported me a lot when I failed. "One-year loss is nothing; keep studying” and similar things.” (G10)

Fam Pract Palliat Care. 2019 Apr;4(1): 
“...my friends this year are, how I should say, better from the perspective of studying. ... we gather and study.” (G2)

"I stayed in the state dormitory (KYK), the rooms were too crowded. I mean, we were four in each room, but the rooms were too small. It was difficult to study; noise, sounds..." (G9)

“.., I know only additional two to three people since the beginning of the semester, and they are those repeating the class.”(G8)

"Of course, I liked them all, but if you are a roommate with somebody, you can at least have the same study schedules. I moved here because I thought this would be a motivation for me.' (G12)

“...we bought a computer, you play games, then you get bored of games, go on your phone all day, staying in bed... throughout the year, beyond sleeping, I spent eighty percent of my time playing games at home..." (G6)

“...I have a very frail constitution. I get easily tired and thus, do not want to join anything." (G9)

“..I started to give private lessons, not because of economic reasons, but to do a bit different activities, I started to give private courses.” (G11)

\section{Discussion}

The prevention of academic failure requires the determination of the factors affecting success [16]. There are many quantitative studies conducted to determine the underlying factors associated with the academic failures of the university students. However, there are very few studies in the qualitative research design. In this sense, our study is important because it is an innovative research aimed at academic failures of medical school students.

Views and beliefs of the students about the effects of the faculty on academic achievement and the revealing titles; some similar characteristics were observed when evaluated in the light of previous research. In our study, the interviewees opined that the teaching style of the instructors, the examination system, and the duration and style of the practical courses at the faculty had an impact on academic achievement. Alos et al. stated that the performances of the students who were exposed to frequent examinations were better than that of the less examined students [17].In a research conducted by Selvi comparing medical students and research assistants concerning the variables affecting academic success; the most important three variables were 'the level of motivation,' 'regular studying,' and 'the quality of the faculty member.' The least important variables, on the other hand, were 'the load of the lecture blocks' according to the students and 'the social environment' according to the faculty members [18]. In our study, the participants did not think that the educational environment would have an impact on their academic achievement. They stated that the teaching method of the instructors would have a positive contribution to their success. In a study conducted by Açik et al, it has been emphasized that faculty members need to follow and implement innovations in the field of medical education as they do in their specialization areas and that their educational and pedagogical abilities should be evaluated during their academic careers. It has been proposed to make a 'training the trainers' course' mandatory for faculty members, including teaching methods, assessment and evaluation, educational psychology, and interpersonal relations [19]. The fact that as to our findings the students' decision to attend a class was not depending on the content, but the style of the instructor is supporting this idea.

As to the material developed by the International Working Group of the Association of Medical Schools in Europe (AMSE), World Federation of Medical Education (WFME), and the Medical Education In Europe (MEDINE) Qualification Working Group, under the heading of "Student support and counseling" it was mentioned that medical schools should provide their students support programs including counseling, and the scope was suggested to be based on the monitoring of the students' development and their social and personal needs. These social and personal needs have included academic support, career guidance, health problems, and physical issues [20]. A counseling service can be beneficial regarding adaptation to the university life, recognition of the curriculum, and adaptation to the courses. It can be said that the students in our study were not aware of the consultancy services. As to the existing bylaws during this study, class I, II, and III students with Integrated Course Exam Grade Point Averages of 85 and above, who scored at least 60 during each of the Integrated Committee Exams were exempted from the Final Exam [21]. Some students did not know that they would be exempt from the final exam over a certain grade point average. Increasing the motivation of the students, increasing the attendance rates of the students, and consequently increasing the desired academic success can be achieved through the dissemination of consultancy services.

When we consider the sub-theme topics discussed regarding the attitudes, beliefs, and opinions of the students about their working behaviors; some of the students connected their absenteeism to factors related to the educators. The students stated that many of the instructors instructed uniformly. Thus, they could not listen and did not want to attend. However, they were of the opinion that some of the trainers made the lessons comfortable with different techniques. Among the reasons for absenteeism in the Altıkurt study were the factors such as the authoritarian attitude of the teachers in the classroom, the inadequacy of communication with the students, and expectations surpassing the possible performances of the students [6]. In a qualitative study conducted by Ozkan et al among the 'perceived problems in medical education in Turkey' the high number of students enrolled ranked highest, followed by the low academic qualifications of the faculty [22].

In our study, the participants expressed mostly troubles in motivation. This is similar to the result of Selvi's study [18]. Lack of motivation, on the other hand, is often related to distancing from studying and getting involved into activities not related to education such as spending time with friends, phone, television, and the internet. For a student in such a situation, studying can become an annoying challenge [7]. Majority of the

Fam Pract Palliat Care. 2019 Apr;4(1): 
interviewees stated that even after repeating the class, they did not gain the habit of regular study, they did not enjoy studying, and they had more fun in doing other activities. It can be expected that increasing the motivation of the students may contribute to their academic success.

Some of the interviewees stated that they did not like to study even during the secondary education, and failed some courses. In a study conducted by Ayyıldiz et al. with nursing students, it was stated that students with lower average GPA before the university had lower GPA at the university too [23]. Hence, it can also be thought that academic failures of university students may be a problem inherited from their past. In the research of Özkan and Cafoğlu, some academic staff suggested that attention should be given to educational issues before the university in addition to those during the medical education [22]. This situation suggested that the acquisition of regular and effective study habits in the early stages of the education would have a positive effect on the whole academic career.

When the emotions and beliefs about medicine are evaluated; Goktas Dortyol in his study conducted with the last year medical students, stated that the reasons for students selecting medical school were in the decreasing order, to have a respectable profession, to have guaranteed job positions, interest in medicine, to help others, having scored high in the placement exam, and influences of the family and environment [24]. These reasons were similar to those why our interviewees decided to study medicine.

Koksal et al, asked medical students "have you regretted it after entering medical school?" They reported that only a few felt regret, half of the participants did not feel regret, and some were not sure [5]. In a study conducted by Açık et al, some of the students stated that they regretted after entering medical school [19]. It may be thought that students' free choice during the section may contribute to the academic achievement. Some of the students who stated that they regretted having entered the faculty of medicine stated that the duration of the study was long and the courses were very intensive [19]. In our study, the students used expressions indicating that they did not regret entering medical school, but their complaints were related to the courses of the medical school and the studentship process. This situation may be related to the fact that the students do not have sufficient and correct knowledge about the university programs they prefer in the secondary education process. Failure to reach adequate and accurate information can lead to unrealistic expectations about the university and disappointments. Some of the suggestions of Koc's work on the mental health of the university students are; establishment of counseling and guidance services in all institutions, initiation of social activities for university students, and exemption of the students with the highest 10 GPA from the KPSS (Public Personnel Selection Examination) [3]. Because the problems of university life are quite similar to other programs except for the differences in the curricula in the medical schools, the promotion of guidance services and the organization of social events can have a very positive impact on academic achievement and mental health.

When the opinions about the effects of the social environment are taken into consideration; it is obvious that accommodation has a significantly more role in the student life than only covering basic needs; it appears to be affecting personal, social, and psychological development [25]. In a study conducted by Koc et al, the highest reasons for stress for university students were 'separation from the family' and 'adaptation to the dormitory and social life of the university' [16]. In our study, we found similar expressions. The participants expressed grievous complaints about the small size, noise, and crowd of the dorm rooms. However, it was also expressed that the dormitory provided easier friendship relations. Students who were with their family stated that they received social support from their families.

\section{Limitations}

Qualitative phenomenological studies do not reveal definitive and generalizable results by their nature. However, they can provide examples, explanations, and experiences that will provide results in helping to better define and understand a phenomenon. The biggest limitation of this study is the inability to generalize our findings. Additionally, not being able to cover all students with academic failure may be considered a limitation too.

\section{Conclusion}

As it is understood from the statements of the students interviewed, it is more enjoyable for students to spend time in other activities instead of studying. This situation can be related to the motivation and their will to study.

We thought that the students lacked sufficient knowledge about the responsibilities and the benefits concerning the examination system. Some of the students did not realize that they could pass the class without entering the final exam when they reached a certain grade point from the integrated committee exams during the year.

Students who experienced failure had low motivation, and self-trust, and had even signs of depressive symptoms had to repeat the practical courses during the next study period with students having similar features, which was considered as a problem area. Under these circumstances, students cannot make new friends cannot get the chance to make friends with peers having better academic success.

Although academic success is associated with many reasons, identifying deficiencies with the possibility of correcting or improving, and taking concrete steps on these issues can have positive contributions. In this context; a priority can be given to providing detailed information to the students about counseling services and providing counseling to the students who are repeating the class by competent trainers, implementing "training the trainers" courses for instructors, ensuring the continuity of course attendance, and improving the shelter and nutrition facilities.

Defining the reasons for academic failures can play a role in the efforts of decision makers to increase student success. Similar qualitative studies can be carried out in medical faculties using different education and examination methods, and students' thoughts and beliefs about academic achievement and failure can be revealed. In this way, the underlying causes can be presented at a wider angle. Elimination of some of the reasons for academic failure may contribute to the training of even more qualified physicians. 


\section{Conflict of interest: None.}

Financial support: None.

\section{References}

1. Sahin I, Sahin-Firat N, Zoraloglu YR, Acikgoz K. [Obstacles for University Students to Continue Their Education] (in Turkish). Egitim Bilim Toplum Dergisi. 2009;7(28):6-20.

2. Ozturk O, Ulusahin A. [Mental Health and Disorders] (in Turkish). 11. Ed. Ankara: Nobel Medical Bookstores; 2011.

3. Koc M, Polat U. The mental health of university students. J Hum Sci. 2006;3(2):1-22.

4. Sarier Y. [Factors Affecting Academic Achievement of Students in Turkey: A meta-analysis study] (in Turkish). Hacettepe Univ J Educ. 2016;1-19. http://dx.doi.org/10.16986/HUJE.2016015868

5. Koksal S et al. [Cerrahpasa School of Medicine Students' Thoughts on Medical Education] (in Turkish). Cerrahpasa J Med. 1999;30(4):2518

6. Altinkurt Y. [The reasons of student absences and the effect of absenteeism on academic achievement] (in Turkish). Dumlupinar Uni Sos Bilim Derg. 2008;20:129-42.

7. Akbaba S. [Motivation in education] (in Turkish). J Kazim Karabekir Edu Fac 2006;(13):343-61.

8. [Reasons for failure of Hacettepe University students] [Internet] (in Turkish). http://www.pdrmer.hacettepe.edu.tr/dosyalar/PDRMER_BABProje_Metin.pdf (access date: 16.11.2016).

9. Elcin M. [The history of medical education] (in Turkish). Hacettepe Med J. 2010;41:195-202.

10. Baser A, Sahin H. [Medical education from Atatürk to the present] (in Turkish). Tip Egitimi Dunyasi 2017;(48):70-83. http://dx.doi.org/10.25282/ted.298428

11. Odabasi O, Sayek I, Kiper N. Undergraduate medical education in Turkey - 2010. Turk Arch Ped 2011;46:322-7. http://dx.doi.org/10.4274/tpa.553

12. Ozvaris SB, Sayek I. [Changes in medical education] (in Turkish). Hacettepe Med J 2005;36(2):65-74.

13. Benli AR, Inci H, Cebecik A, Sunay D. [Comparison of the Faculty of Medicine and Faculty of Basic Medical Sciences Course Hours in Turkey] (in Turkish). Tip Egitimi Dunyasi 2018;51:13-20. http://dx.doi.org/10.25282/ted.327551

14. [Izmir Katip Celebi University] [Internet] (in Turkish). http://tip.ikc.edu.tr/S/13395/tarihce (Access date: 15.05.2016).

15. Yildirim A, Simsek H. [Qualitative Research Methods in Social Sciences] (in Turkish). 8th Ed: Ankara. Seckin Publishing; 2011.

16. Koc M, Avsaroglu S, Sezer A. [The Relationship Between Academic Achievements of University Students and Problem Areas] (in Turkish). Selcuk Universitesi Sos Bilim Enstitüsü Derg. 2004;11:483-98.

17. Alos SB, Caranto LC, David JJT. Factors Affecting the Academic Performance of the Student Nurses of BSU. Int J Nurs Sci. 2015;5(2):605. http://dx.doi.org/10.5923/j.nursing.20150502.04

18. Selvi H. [Scaling of the Variables Affecting Academic Achievement of Doctor Candidates with Bilateral Comparisons] [Internet] (in Turkish). http://kongre.teged.org/UTEK16/abstract/hekim-adaylarinin-akademik-basarilarini-etkileyen-degiskenlerin-ikili-karsilastirmalaryontemiyle-olceklenmesi (Access date: 06.07.2018).

19. Acik Y, Oguzoncul F, Polat SA, Gungor Y, Gungor L. [Medical education at Firat University Faculty of Medicine students and their thoughts about graduation] (in Turkish). Toplum ve Hekim. 2002;17(3):195-201.

20. Sayek I, Elcin M, Odabasi O, Turan S. [World Federation of Medical Education Universal Standards for Improving Quality in Medical Education European Specifications] (in Turkish). 2007. http://www.ttb.org.tr/kutuphane/standartlar.pdf (Access date:15.11.2016)

21. [Izmir Katip Celebi University Examination Directive] [Internet] (in Turkish). https://kms.kaysis.gov.tr/Home/Goster/64049 (Access date: 2.10.2018).

22. Ozkan S, Cafoglu Z. [A Case Study of Faculty of Medicine on Perceived Medical Education and Problems] (in Turkish). Tip Egitimi Dunyasi 2003;(12):6-18.

23. Ayyıldız T, Konuk Sener D, Veren F, Kulakci H, Akkan F, Ada A, et al. [Factors Affecting Academic Achievement of Nursing Students] (in Turkish). ACU Saglik Bil Derg 2014(3):222-8.

24. Goktas Dortyol B. [The thoughts, career choices and influencing factors of postgraduate students.] (in Turkish). Tip Egitimi Dunyasi 2017;(50):12-21. http://dx.doi.org/10.25282/ted.346397

25. Arli E. [Investigation of the Impact of Housing on University Students' Personal and Social Development and Academic Achievement by Focus Group Interview] (in Turkish). Yuksekögretim ve Bilim Derg 2013;3(2):173-8. http://dx.doi.org/10.5961/jhes.2013.073 